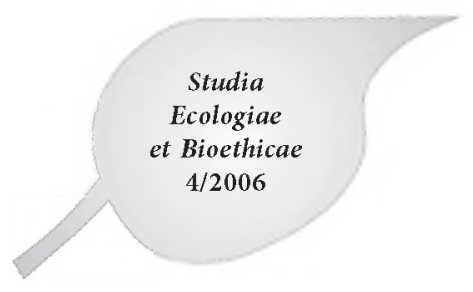

Jan SANDNER

JEiB UKSW Warszawa

\title{
Wybrane problemy gospodarki wodnej w ujęciu holistycznym
}

Coraz częściej stajemy się świadkami różnych katastrof środowiska przyrodniczego na Ziemi. Nie minęły jeszcze echa trzęsień Ziemi, jakie nawiedziły Japonię, Meksyk, czy USA, a przed nami kolejne zagrożenia, cykliczne susze na przemian z powodziami, nawiedzające kontynent Azji Południowo-wschodniej, ale ostatnio coraz częściej i Europę.

Porównywanie ze sobą tych dwóch naturalnych żywiołów, nie jest możliwe. Powodują one wprawdzie, często porównywalne w skutkach katastrofy środowiska, mają podobną siłę rażenia, dotyczą tej samej sfery, ale różnią się jednak genezą powstania. O trzęsieniach Ziemi decydują zupełnie inne mechanizmy przyrodnicze na które człowiek, nie ma żadnego wpływu. Zupełnie inaczej jest w przypadku zagrożeń ze strony kataklizmów powodziowych. Na nie ma wpływ wiele czynników, wśród których, niestety coraz większy udział ma również człowick.

W okresie ostatnich kilku lat, nie jest przypadkiem fakt, że właśnie najbogatsze kraje coraz częściej są nękane katastrofalnymi powodziami. W przypadku krajów Europy zachodniej, powodzie stają się już prawie zjawiskiem cyklicznym. Niewątpliwie jednym z czynników, który jest za nie odpowiedzialny to zmieniający się klimat. Jeszcze kilkanaście lat temu, zima kojarzyła nam się z mrozem i śniegiem. Rozregulowanie rytmu pór roku, jest jednym z elementów, które decydują o powstawaniu anomalii, jakich jesteśmy coraz częściej świadkami. Obydwie te anomalie i tak prowadzą do gwałtownego kurczenia się wszystkich zasobów wody słodkiej. Dowodem tego są chociażby wyniki badań przepływu w głównych rzekach z terenu Polski, takich, jak: Odra, Wisła, Bug, czy Narew. We wszystkich wymienionych ciekach na przestrzeni lat 1998-2004 zmniejszył się w nich przepływ wody od około $20-50 \%{ }^{1}$. Oczywiście jednym z czynników powodujących ten stan jest zmieniający się klimat.

GUS, 2004, Ochrona Środowiska, Warszawa, s. 507. 
Na temat zmian klimatu napisano już „opasłe tomy”. Główną teorią, coraz powszechniej lansowaną przez klimatologów jest tzw. efekt cieplarniany ${ }^{2}$, wywołany działalnością gospodarczą człowieka. Bezpośrednio odpowiedzialny za ten proces jest dwutlenek węgla. Mechanizm występowania „efektu cieplarnianego”, uzależniony jest od kilku czynników. Istota tego zjawiska, polega na zatrzymywaniu energii cieplnej w warstwie powierzchniowej Ziemi, uniemożliwiając $w$ ten sposób wydostanie się zakumulowanej energii do przestrzeni kosmicznej. Proces ten stanowi wtórny etap przedostawania się promieniowania słonecznego do powierzchni Ziemi. Zawartość $\mathrm{CO}_{2}$ w atmosferze prowadzi do niekontrolowanego wzrostu temperatury atmosfery i powierzchni Ziemi. Zjawisko to szczególną rolę zaczęło odgrywać dla egzystencji człowieka, dopiero w ostatnich latach. Bezpośrednim jego powodem jest gwałtowny rozwój procesu industrializacji, a także globalizacji ${ }^{3}$ naszego życia. Procesowi industrializacji, zawsze towarzyszy w mniejszym, lub większym stopniu spalanie węgla. Oczywiście zwiększony efekt cieplarniany jest również spowodowany przez wzrost metanu, tlenku azotu, chlorofluorowęglowodorów, zwanych też freonami i ich substytutów hydrofluorowęglowodorów i perfluorowęglowodorów oraz ozonu i pary wodnej ${ }^{4}$.

Wzrost $\mathrm{CO}_{2} \mathrm{w}$ atmosferze jest, nie tylko groźny ze względu na powstawanie „efektu cieplarnianego", ale także ma negatywny wpływ na rośliny. Według naukowców, rośliny dobrze rozwijają się jedynie do pewnej granicy zawartości tego gazu w atmosferze. W momencie jej przekroczenia oraz utrzymywania się przez dłuższy czas, może dojść do nieobliczalnych dla nich konsekwencji. Rośliny, mogą wtedy ulec nieodwracalnym uszkodzeniom. Jeśli zawartość $\mathrm{CO}_{2} \mathrm{w}$ atmosferze, będzie się powiększać w obecnym tempie (pomimo zmniejszenia procesu spalania węgla), to niestety należy się spodziewać dalszego wzrostu temperatury na Ziemi. W Polsce na przestrzeni ostatnich 10 lat obserwuje się stałą tendencję spadkową w emisji $\mathrm{CO}_{2}$. Pomimo tego skutki tego procesu występującego na Ziemi w skali globalnej, będą prawdopodobnie najbardziej odczuwalne w najbliższym dziesięcioleciu. Konsekwencje jego będą groźne dla całego środowiska przyrodniczego. Wśród pierwszych objawów tak rozregulowanego środowiska, należy się spodziewać uruchomienia procesu topnienia lodowców podbiegunowych oraz Grenlandii (ocenia się, że już w 2006 roku proces ten nabrał niezwykłego przyspieszenia). Skutki tego procesu dla wielu milionów mieszkańców Ziemi będą katastrofalne. Poziom wód w morzach świata podniesie się w takim

TJeERd H. van ANDEL, Nowe spojrzenie na stara planete, zmienne oblicze Ziemi, Wydawnictwo PWN, Warszawa 2005, s. 304.

3 M. CZerny, Globalizacja a rozwój, Wydawnictwo PWN, Warszawa 2005, s. 240.

4 A.M. Mannion, Zmiany środowiska Ziemi, Historia środowiska przyrodniczego i kulturowego, Wydawnictwo PWN, Warszawa 2001, s. 450. 
stopniu, że dojdzie do zatopienia znacznej części kontynentów Ziemi. Nie w lepszej sytuacji, będą tereny położone znacznie wyżej, które prawdopodobnie zamienią się wtedy w stepy i pustynie.

Z badań prowadzonych w ramach programu „Desert Watch” Europejskiej Agencji Kosmicznej, procesowi pustynnienia uległo już 300 tysięcy kilometrów kwadratowych obszaru w rejonie Morza Śródziemnego (jest to teren zamieszkały, łącznie przez 16.5 miliona ludzi o powierzchni porównywalnie większej niż Wielka Brytania). Dowodem ostatecznego uruchomienia tych procesów są odnotowane przez meteorologów tzw. anomalie letnie, których jesteśmy ostatnio świadkami. Lato 2003 (najgorętsze lato we Francji od 150 lat), trzy kolejno postępujące najgorętsze lata stulecia w Europie to: 2001, 2002, 2003 oraz 2006. Międzynarodowy Zespół ds. klimatu IPCC, powołany przez Światową organizację Meteorologiczną, uważa, że do końca tego wieku średnia temperatura we Włoszech podniesie się o $7-8^{\circ} \mathrm{C}^{5}$. Analizując tegoroczne dane klimatyczne w zupełnie innym wymiarze, należy postrzegać zjawiska, składające się na przyczyny obecnego stanu środowiska przyrodniczego. Jedną z nich z pewnością jest ciągle niewystarczająco kontrolowany rozwój branży energetycznej. Na obecnym etapie rozwoju energetyki światowej uważa się nadal, że proces ten odbywa się praktycznie poza kontrolą. Na regulacje emisji zanieczyszczeń, tego najbardziej niebezpiecznego procesu w skali ogólnoświatowej, ma także wpływ fakt, że władze wielu krajów świata po prostu, nie mają żadnej polityki energetycznej.

Właśnie w opisywanym zjawisku „efektu cieplarnianego" upatruje się większości nieszczęść, które spotykają nas na Ziemi. Proces ten, nie tylko powoduje ocieplenie klimatu w skali globalnej, ale także ma już dzisiaj również wpływ na zmianę cyrkulacji prądów powietrznych, a co za tym idzie i opadów ${ }^{6}$. W tej sytuacji, nie jest to przypadek, kiedy dochodzi do gwałtownych opadów deszczu na terenach nizinnych, porównywalnych w swojej wielkości i nasileniu z terenami górskimi. Skutki tego typu zjawisk kończą się najczęściej tragiczne. Tereny te z punktu widzenia swojej orografii (ukształtowania powierzchni), nie są w stanie przyjąć takiej ilości wody w tak krótkim okresie czasu. Na masę wody, która znajduje się w ten sposób na tych terenach, nakłada się woda, która w znacznie przyspieszonym tempie przemieszcza się ze zlewni rzek z obszaru górskiego. W takim dopiero momencie okazuje się, że czlowiek, który do wczoraj uważał, że świetnie sobie daje radę w ujarzmianiu środowiska przyrodniczego, nagle staje się bezradny. Nałożenie się na siebie takich procesów, za które on jest bezpośrednio odpowiedzialny, typu: „efekt cieplarniany”, degradacja powierzchni ziemi, regulacja cieków wodnych, powoduje nieobliczalne konsekwencje.

5 Environment for Europeans, Magazine of the Directorate - General for the Environment, Europe warms to Commision climate change campaign, Publishing by European Commision, (No.25) 2006.

6 W. Che€micki, Woda, zasoby, degradacja, ochrona, Wydawnictwo PWN, Warszawa 2001, s. 305. 
Okazuje się, że najbardziej narażone na powódź są wbrew pozorom kraje najlepiej rozwinięte gospodarczo. Spowodowane jest to, między innymi wytrzebieniem dużej powierzchni obszarów leśnych (pod zabudowę miejską i rolnictwo) oraz niewłaściwą regulacją cieków wodnych. Środowisko przyrodnicze, które nas otacza tworzy pewną całość. Do momentu ingerencji w nie człowieka, było ono w stanie kontrolować wszystkie procesy przyrodnicze. Regulacja cieków wodnych przez człowieka, ostatecznie zaburzyła tą równowagę.

Woda znajdująca się w rzekach, musi mieć kontakt ze swoim podłożem. Jest to zasadniczy czynnik decydujący o możliwości wzajemnego zasilania (rzek i terenów sąsiadujących z nią). Proces ten, może funkcjonować w zależności od dyspozycyjnych zasobów. Zasilanie tego typu, spełnia także rolę naturalnego procesu zwanego retencją wodną (zatrzymywanie części zasobów wodnych). Fakt przyspieszania biegu rzek, poprzez ich obudowywanie, a także likwidowanie naturalnych rozlewisk, powoduje, że woda płynie takimi ciekami coraz szybciej. W rezultacie czego, staje się niedostępna dla procesów odpowiedzialnych za jej retencję. Przykładem takiej rzeki, może być dzisiejszy Ren. Na terenie Szwajcarii przypomina on raczej obudowaną rynnę, niż naturalną rzekę. Skutki działalności człowieka, najlepiej są widoczne, podczas pomiaru szybkości przepływu wody $w$ tej rzece. Okazuje się, że na przełomie ostatnich czterdziestu lat, przyspieszyła ona swój bieg prawie dwukrotnie. W latach 50-tych, czas przepływu wody z terenu Szwajcarii do jej ujścia wynosił 70 godzin. Dzisiaj do pokonania tej odległości, potrzeba niespełna 30 godzin. Rzeka zagospodarowana przez człowieka, lub inaczej wyregulowana, praktycznie w niczym, nie przypomina rzeki naturalnej. Zmiana budowy przekroju uregulowanego cieku wodnego, jest głównym czynnikiem odpowiedzialnym za powodzie, które z coraz większą siłą nawiedzają Europę zachodnią również podczas zimy.

Rzeka w której, nie doszło do ingerencji człowieka, posiada wiele charakterystycznych elementów, które wytworzyły się w sposób naturalny. Charakteryzuje się ona odpowiednią szerokością koryta rzecznego, wykształconego w zależności od rodzaju skały macierzystej. Od rodzaju materiału z jakiego zbudowane jest podłoże ma także wpływ wielkość jej koryta, tarasów zalewowych, dna doliny, a także ukształtowanie profilu całej doliny rzecznej. W zależności od tych czynników, kształtuje się dopiero właściwy nurt rzeki. Bardzo istotną rolę dla prawidłowego przepływu wody ma także, samo koryto rzeczne. Znajdują się tam, takie charakterystyczne elementy budowy, jak: ławice czy meandry. Właśnie te naturalnie wykształcone składowe rzeki, są odpowiedzialne za jej prawidłowy bieg. Dzięki nim w momencie wezbrań, woda ma możliwość naturalnego rozlania się $w$ pasie meandrowym rzeki na długim nizinnym odcinku. Duze znaczenie ma też naturalna krętość koryta? W ten sposób nurt rzeki, może zostać naturalnie

M. KLimaszewski, Geomorfologia, Wydawnictwo PWN, 1978, s. 1098. 
wyhamowany już w górnym jej biegu. Niestety wszystkie rzeki, które poddano regulacji, w pierwszej kolejności pozbawiono tych naturalnych cech. Natomiast to co w zamian wprowadzono, czyli głębokość koryta oraz wyznaczenie kierunku nurtu, wykonano sztucznie na podstawie symulacyjnych obliczeń matematycznych. Oczywiście za podstawę ich przyjęto wartości średnie, wielkości przepływającej wody. W momencie, gdyby do obliczeń wykorzystano wartości z sytuacji ekstremalnych, to okazałoby się, że koszty regulacji takiej rzeki, byłyby całkowicie nieopłacalne (ingerencja w środowisko, byłaby całkowicie nieopłacalna). Niestety, ludzie decydując się na regulację rzek w krajach Europy zachodniej, przyjęli wariant optymistyczny. Skutki tych decyzji, które obserwujemy po kolejnych powodziach, jakie tam występują, będą coraz bardziej odczuwalne.

Jeżeli w krajach zachodnio-europejskich większość dużych rzek w ciągu ostatnich kilkunastu lat poddano tego typu przebudowom, to na rezultaty tych działań, jak widać nie trzeba będzie długo czekać. Nie pomagają wtedy, nawet najlepsze zbiorniki retencyjne. Siła uderzenia tzw. „dużej wody” jest praktycznie, nie do wyhamowania. W przypadku największych powodzi, dość duży wpływ, może mieć również niekorzystny układ temperatur powietrza (w okresie bezpośrednio poprzedzającym powódź). Po dużych mrozach w wyniku których, dochodzi do silnego zmrożenia gruntów, następuje gwałtowny wzrost zjawiska, polegającego na spływie powierzchniowym wody deszczowej. W ten sposób woda, która w normalnych warunkach powinna ulec procesowi infiltracji, zostaje przemieszczona, zasilając dodatkowo falę powodziową. Koszty szkód, jakie powstają w wyniku takich sytuacji, kilkakrotnie przekraczają wszystkie zyski, jakie uzyskuje się z regulacji tych cieków wodnych.

W Polsce „na szczęście” regulacji (ze względu na brak środków finansowych) poddano jedynie nieliczne krótkie odcinki i to tylko niektórych rzek. Tam, gdzie już zresztą ją przeprowadzono, została ona wykonana najczęściej minimalnym kosztem. Dzięki temu, nie mamy koryt rzecznych, przypominających np. rzekę Ren. Niestety w przypadku gwałtownego wzrostu opadów deszczu, musimy się jednak liczyć z groźbą fali powodziowej. Najsłabszym ogniwem w Polskim systemie hydrotechnicznym są zbiorniki retencyjne. Wprawdzie posiadamy kilkanaście większych zbiorników wodnych o pojemności przekraczającej nawet $50 \mathrm{hm}^{3}$, ale najczęściej są to konstrukcje przestarzałe. Największy z nich zbiornik na Solinie został uruchomiony jeszcze w 1968 roku, nie lepiej jest w przypadku Włocławskiego (1970), Jeziorskiego (1970), Rożnowa (1941), Goczałkowic (1956), czy Otmuchowa (1933). Podobnie jest w przypadku małych zbiorników. Najstarsze z nich, pochodzą jeszcze z tamtego wieku. Wiek tych zbiorników powoduje określone konsekwencje. Należy liczyć się z tym, że większość z tych najstarszych budowli jest już w dużym stopniu zdekapitalizowana. Proces ten, między innymi polega na tym, że tracą one swoją pojemność z powodu akumulacji materiału osadowego niesionego w rzece. Dlatego trzeba się liczyć z tym, że 
faktyczna pojemność większości z nich, nie pokrywa się z ich rzeczywistą. Fakt ten, może pociągnąć daleko idące konsekwencje w przypadku powstania dużej fali powodziowej, którą zbiorniki te powinny powstrzymać. Nie lepszą sytuację zastajemy w przypadku, innych budowli hydrotechnicznych. Wiele wałów przeciwpowodziowych, pamięta jeszcze lata Księstwa Warszawskiego. Brak nowych inwestycji w momencie, kiedy i tak doszło już do ingerencji człowieka w skomplikowany system wodny środowiska przyrodniczego, będzie w przyszłości poważnym zagrożeniem. Wprawdzie zagrożenie dużą powodzią w Polsce z pewnością jest znacznie mniejsze niż w przypadku Niemiec, Austrii czy Francji, jednakże nie wolno jest nam tego problemu bagatelizować. Przykładem, mogą być powodzie, które nawiedziły nasz kraj w ostatnich latach.

W Polsce, aby uchronić się w przyszłości przed powodziami, powinien powstać od podstaw nowy systemowy projekt budowy (obejmujący w sposób całościowy) stosunków wodnych. System ten w swoich założeniach powinien obejmować, skomplikowaną problematykę regulacji stosunków wodnych, z uwzględnieniem pełnej harmonii z innymi elementami środowiska przyrodniczego. W przypadku, nie zachowania tego warunku czekać nas będą, nie tylko zagrożenia spowodowane powodziami, ale również ponawiające się deficyty wodne szczególnie odczuwalne w okresie letnim. Niektóre kraje Europejskie analizując swoje błędy, popełnione w gospodarce wodnej na przestrzeni ostatnich dziesiątek lat, postanowiły działać. Najlepszym tego przykładem jest Austria, która wykorzystując do tego przewodniczenie Komisji Europejskiej w ramach programu „Zrównoważony rozwój” (w pierwszej połowie 2006 roku), wprowadziła do niego nowe priorytety. Tym nowym priorytetem dla Austrii w ramach, tego programu jest "przeprowadzenie szeroko zakrojonych działań, mających na celu zapobieganie powodziom, a także wprowadzenie procedur zarządzania kryzysowego wraz propozycjami badań naukowych w tej dziedzinie".

Problem zagrożenia stosunków wodnych w naszym kraju jest od pewnego czasu również dostrzegany. Za obecny stan tych stosunków odpowiedzialnych jest wiele czynników, począwszy od aktualnie prowadzonej polityki, skończywszy na poziomie edukacji społeczeństwa w zakresie problematyki hydrologicznej. Właśnie na problematykę niewystarczającej edukacji, bardzo duży nacisk położył w swoim wystąpieniu Roman Skąpski z IMiGW, podczas konferencji Pt. Zagrożenia bezpieczeństwa wodnego ${ }^{8}$, zorganizowanej w 2005 roku przez Instytut Problemów Współczesnej Cywilizacji. Moim zdaniem jest to problem znacznie szerszy, niż był poruszony w ramach tego wystąpienia, wymagający całkowicie odrębnej analizy merytorycznej. Jest to wielopoziomowy problem,

R.SKĄPSKI, Ochrona przed zagrożeniami powodziowymi, Materiały z konferencji pt. Zagadnienia bezpieczenstwa wodnego, Instytut Problemów Wspólczesnej Cywilizacji, Wydawnictwo SSGW, Warszawa (XXXIII) 2005, s. 7-23. 
związany z całym procesem edukacji proekologicznej, prowadzonej w naszym kraju we wszystkich typach szkół, włącznie ze szkołami wyższymi. Istotą tego problemu jest brak systemowego procesu edukacji środowiskowej. Procesu, który opierałby się na holistycznym podejściu do zjawisk środowiskowych. Szkody wynikłe z niewłaściwego modelu nauczania społeczeństwa są już coraz bardziej widoczne.

Na UKSW w ramach studiów na kierunku ochrona środowiska, podjęto po raz pierwszy próbę systemowego nauczania podstawowych przedmiotów przyrodniczych. Obecnie są one jeszcze wykładane w ramach, wspólnych bloków przedmiotowych, jak: Hydrologia, Gospodarka wodna, Gleboznawstwo, Geologia dynamiczna, czy Geomorfologia, jednakże program ich (w zakresie wykładów oraz ćwiczeń), dostosowywany jest do nowych potrzeb nauczania. Wynikiem tego nowego modelu nauczania ma być zdobycie niezbędnej wiedzy (biorących w nim udział uczestników) w zakresie funkcjonowania środowiska, jako całości oraz relacji pomiędzy poszczególnymi jego elementami na określonym poziomie organizacji. Proces ten jest niezbędny w celu prawidłowego zarządzania środowiskiem i rozwiązywania sytuacji kryzysowych.

\title{
The selected holistic concept of water management problems
}

\begin{abstract}
The Author, in the article discusses proper water management problems. He presents the primary causes resulting in the degradation of water relations in the form of regular occurrences of floods or dry spells in Europe. In the article, degradation of water relation problems taking place in our country are compared to those in Germany or Austria. He points the need of systematic teaching of basic environmental subjects within the holistic concept constituting a tool in shaping pro-ecological consciousness.
\end{abstract}

